\title{
EL ORGULLO PROVINCIANO DE DON PEDRO DE ALBA
}

PEDRO DE ALBA, Niñez y juventud provincianas, Aguascalientes, Instituto Cultural de Aguascalientes, 1996.

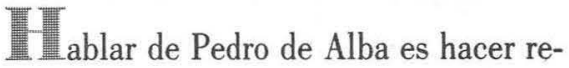
ferencia a uno de los hombres que participaron de manera destacada en la reconstrucción del país, una vez terminada la revolución que dejó aproximadamente 2 millones de muertos en un país que apenas tenía 14 millones de habitantes. Desde el Congreso de la Unión, Pedro de Alba impulsó medidas tendientes a organizar la administración pública para responder a las más grandes necesidades del pueblo mexicano y a las aspiraciones de aquellos que tomaron las armas para tener un mejor futuro.

Hace poco, por extrañas coincidencias, con estudiantes de la Maestría en Investigación Educativa de la Universidad Au- tónoma de Aguascalientes, analizábamos la creación de la Secretaría de Educación Pública en 1921, el proyecto educativo y cultural de José Vasconcelos y la propuesta de federalizar la educación ante la incapacidad de los municipios y estados de hacerse cargo para atender el ambicioso proyecto de llevar las letras a todos los rincones del país. Al discutir un texto de José Iturriaga sobre estos temas, nos encontramos unas líneas sugerentes y oportunas:

En las sesiones parlamentarias de fines de 1920 y de 1921, destinadas a discutir la iniciativa para reformar la Constitución e introducir la Secretaría de Educación Pública en la Ley Orgánica de Secretarías de Estado, el presidente de la Comision, Pedro de Alba, fue el defensor más pertinaz y lúcido de dicha reforma.

Esta referencia me puso a pensar en la trayectoria de este intelectual de San Juan de los Lagos, Jalisco, y en la necesaria búsqueda de su participación en los 
Debates del Congreso. Su postura y su activismo era la continuación de aquellas discusiones apasionadas y brillantes que se dieron, entre 1916 y 1917, entre los grupos encabezados por Félix Fulgencio Palavicini y Francisco Múgica para elaborar el artículo tercero constitucional.

La vida de Pedro de Alba, francamente, es digna de admiración. Fue un médico lleno de humanismo, político progresista y de principios firmes, legislador y diplomático activo, periodista persistente y agudo, historiador comprometido y educador con ideas y proyectos claros. Se puede estar en desacuerdo con algunas de sus propuestas, pero no se le puede negar una trayectoria profesional destacada y una participación social decisiva. Fue un persona cabal que tuvo que colaborar en un momento de la historia de México que más necesitaba de hombres y mujeres con ideas y propuestas.

Del libro, concretamente de la referencia que su hijo Jorge de Alba hace de las influencias que recibió Don Pedro, me llamó la atención ese apego a la obra y pensamiento de Fray Bartolomé de las Casas, que, según Andrés Iduarte, "lo acompañaba en el sueño como en la vigilia". Por ello no era casual, dice este biógrafo, que se le identificara con un "socialismo cristiano" muy bien adosado con "liberalismo anticlerical".
Los textos de Don Pedro de Alba son amenos, deliciosos, ricos en imágenes y recuerdos que no sólo nos ofrecen fragmentos de una vida intensa, sino que representan una fuente rica y extraordinaria para comprender y hacer la historia de la vida cotidiana de la ciudad de Aguascalientes, con sus lugares típicos, como el jardín de San Marcos, el Instituto de Ciencias, el Parián, el Liceo de Niñas y algunos barrios, así como de una pueblo alteño tan cercano y, de algún modo, tan nuestro: San Juan de los Lagos. Y digo que nos es muy cercano, porque recuerdo como en la presentación del libro de Ramón López Velarde, Suave Patria y otros poemas, se dice: "nació en un rincón casi desconocido de la provincia (Jerez, Zacatecas)". Yo me pregunto: Desconocido, para quién. Obviamente, se trata de alguien que escribe "desde el centro".

Cuestión de perspectiva. No hay chovinismo alguno, como tampoco lo tuvo Don Pedro, quien al referirse a su pueblo natal era agudo y crítico. San Juan, según sus palabras, seguía siendo un pueblo inmóvil a través de los siglos, un pueblo hermético con hogares de familias conservadoras como recintos amurallados que sólo penetraban los parientes o los amigos. San Juan era, y tal vez sigue siendo, un pueblo con gente que tiene deseos de escapar y liberarse de la rigidez ceremoniosa. 
De los textos me llamaron la atención muchos pasajes, pero quisiera compartir brevemente algunos de ellos. El inicio del libro, por ejemplo, atrae de inmediato: "Las cosas que más admiré de niño, dice Don Pedro, fueron el río y el puente de mi tierra". El río, que abrazaba amorosamente al pueblo, "era una escuela de igualdad; balneario del pobre y el rico, campo de paseo para muchachas de todas las clases sociales, estadio de competencia atlética en las que no había privilegios de nacimiento". Era un río generoso, siempre dispuesto a recibir a todos con la misma sonrisa.

Obviamente, la parte que se refiere a las peregrinaciones también atrae y arrebata la atención de inmediato:

vienen de lejos y han pasado fatigas y penalidades para llegar a la Basílica que guarda la Virgen Milagrosa. Algunos de ellos ofrecieron venir descalzos, otros entran de rodillas desde la lejanía donde se contemplan las torres y otros se han impuesto voluntariamente las torturas medievales colocándose una penca de nopal en el pecho descubierto y otra en la espalda desnuda. Fervor, inocencia y piedad que hablan el lenguaje de los creyentes desamparados y de los pecadores que buscan su redención con el martirio.

Al terminar su primaria, cuenta Don Pedro que sintió un gran deseo de conocer tierras lejanas y, como no había los recursos, se conformaba y sorprendía cuando salía a Lagos de Moreno y a la
Chona. Aguascalientes estaba ya muy lejos, pero con el tiempo fue allí donde se quedó a estudiar.

Como profesionista interesado en la educación, al leer el libro puse atención especial en el paso de Don Pedro por la escuela y la influencia que tuvo de la gente de su pueblo. Él mismo, al momento de escribir sus memorias, parece haberse hecho estas preguntas y nos previene:

Quien lea mis remembranzas de costumbres y personajes de mi niñez puede creer que el ambiente estaba totalmente dominado por la oracion y la Feria con pretextos religiosos. Había excepciones en el grupo de los inconformes liberales. Desde entonces se les llamaba librepensadores. No iban con la corriente. Tenían cierto aplomo en sus opiniones y presencia de hidalgos en las discusiones. Se les respetaba de lejos. Por lo menos, en mí tuvieron influencia.

De igual manera, habla cómo los jóvenes que iban a estudiar a Guadalajara volvían a San Juan y ofrecían las primacías de su profesión al mismo tiempo que reactivaban el ambiente cultural del pueblo, impulsando obras teatrales y veladas literario-musicales. Su afición por la música, la literatura y la vida intelectual, en general, se reforzaron años más tarde, cuando llegó a la ciudad de Aguascalientes y se inscribió en el Instituto de Ciencias. Don Pedro nos habla de su primer 
día de clases, del director Ignacio N. Marín, del fundador Jesús Terán, del "eterno femenino", de las lecturas de Garcilaso, Cervantes, Lope de Vega y Quevedo que le recomendaba el Doctor Francisco C. Macías y de su primer contacto con Enrique Fernández Ledesma.

Fue precisamente Fernández Ledesma, que ya tenía tiempo en el Instituto, quien le insistía en que era necesario tener una cultura general y, por lo tanto, que había que leer otras obras además de las recomendadas en clase. Curiosamente, una de las primeras obras que le prestó fue La vida Bohemia de Enrique Murger. Don Pedro comenta como poco a poco se fueron uniendo a esta inquietud intelectual, que iba más allá de la vida escolar, jóvenes como Saturnino Herrán, Manuel M. Ponce y quien sería su mejor amigo de entonces: Ramón López Velarde. Como puede observarse, el grupo estaba integrado por personas que más tarde harían grandes aportaciones al país, en el mundo de las artes. El mismo Don Pedro escribe con signos de admiración: "iQué afortunado fue para todos que hubiéramos coincidido en el Instituto de Ciencias de Aguascalientes!".

Al leer el texto de Pedro de Alba, pensé en la necesidad de hacer una investigación de esa generación, nacida a fines del siglo XIX y principios del XX, entre los que se encuentran, precisamente Ramón López Velarde, Manuel M. Ponce, Enrique Fernández Ledesma y Saturnino Herrán, entre otros.

La lectura del libro, bien puede explicarse con las mismas palabras que él dedicó al trabajo de Rubén Romero: él capta los paisajes de provincia y de esas canteras de sonrisa y sátira de la vida se desprenden realidades que "irradian gracia y simpatía, que a veces resulta un poco melancólica".

Salvador Camacho Sandoval DEPARTAMENTO DE EDUCACION/UAa 